Historic, Archive Document

Do not assume content reflects current scientific knowledge, policies, or practices. 



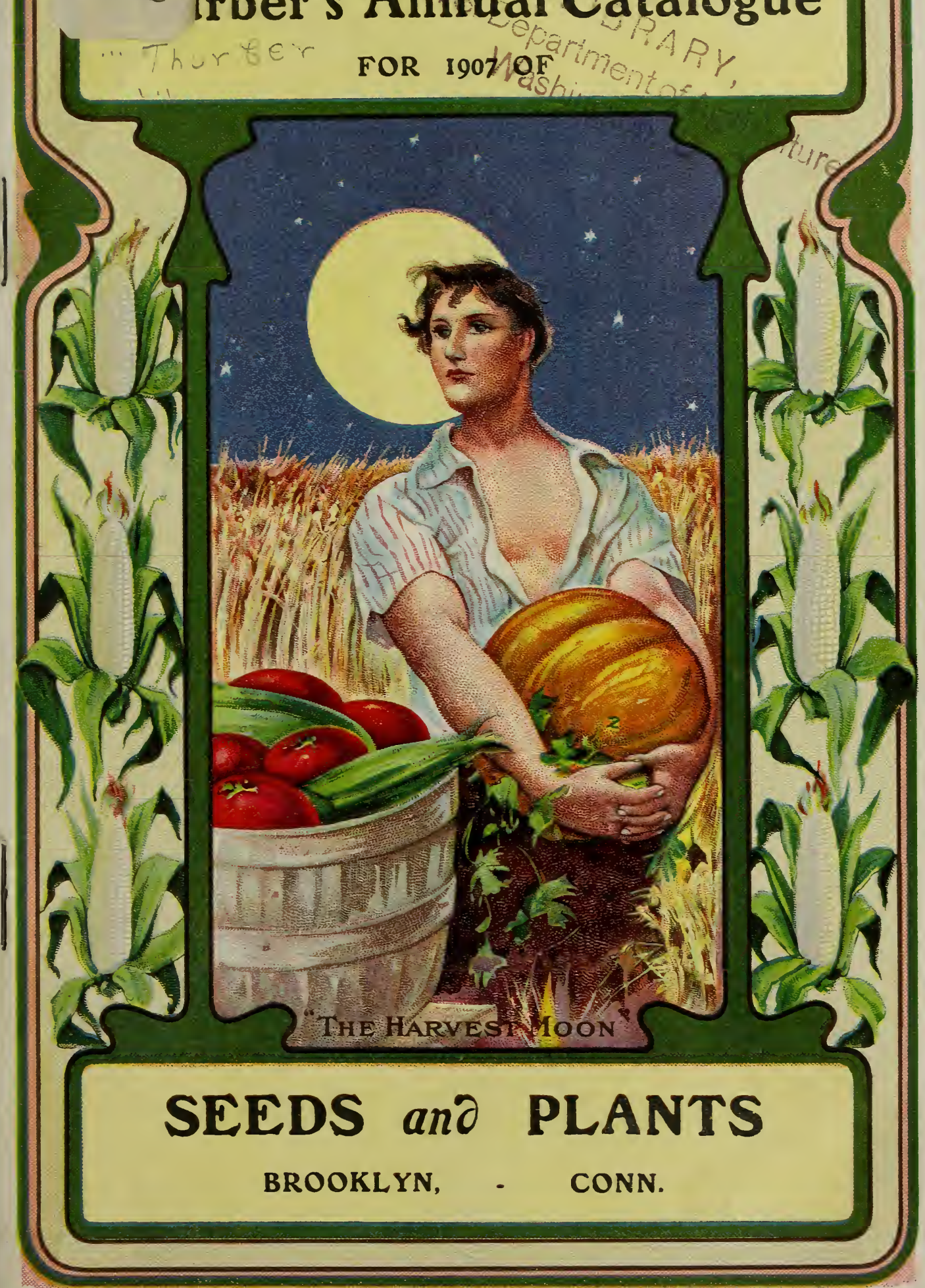





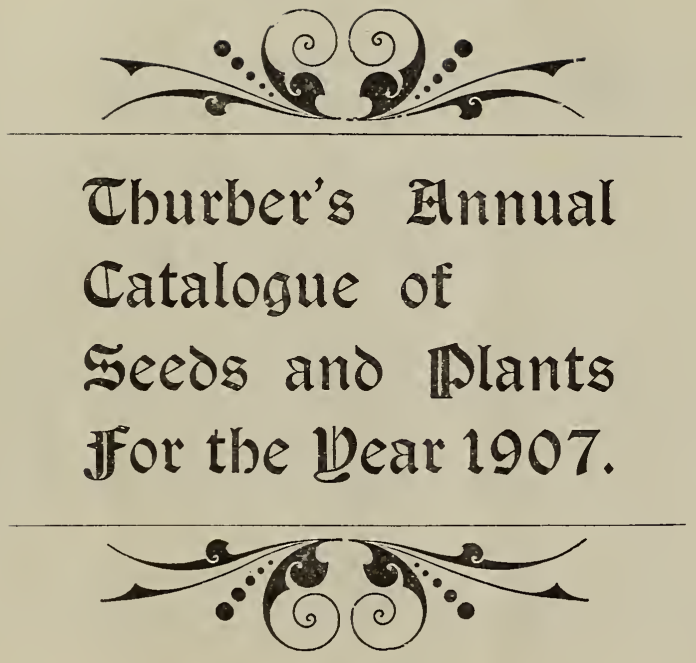




\section{TO THE PUBLIC.}

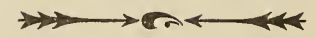

I thank my many patrons for the favors shown me in the past, and would ask those who have niever dealt with me, to compare prices and test the quality of my seeds, witit those whom they have formerly deait, and trust that from olà and new customers I will receive mity share of your patronage.

My aim has been to deal only in the cest quality of seeds; it will be my purpose in the future.

There are so many reasons why the best seeds jo not always germinate, that it must be distinctiy understood thai my seeds are not under any guarantee jor the produrtiveness of the crop.

\section{William R. Thurber,}

Brooklyn, Conn. 


\section{SPECIAL OFFER}

\section{ON \\ FLOWER SEEDS.}

As an additional inducement to indiriduals who desire to possess a large collection, for or the formation of clubs for the same object, we offer to send by mail, free of postage, to any address in the United States or Canada, the following :

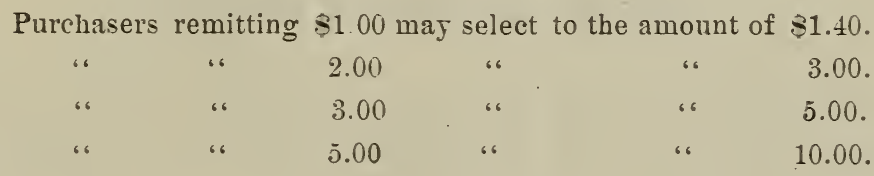

REMEMBER this discount is on Flower seeds only.

In sending orders for Flower Seeds by mail, it will only be necessary to give the date of Catalogue from which the selection was made, and the NUMBER instead of the name of the rarieties. 


\section{Seeds by Mail, Freight or Express.}

Flower or Vegetable Seeds ordered by the packet, ounce or quarter pound will be sent by mail or express at catalogue prices. When Vegetable seeds are ordered by-mail in quantities of one-half pound and upwards, purchasers must send eight cents per pound for postage. When Peas and Beans are ordered by the quart, by mail, add fifteen cents per quart; Corn, add ten cents per quart.

\section{About Ordering.}

In ordering please write your name, post-office and state plainly. Remittances should be made either by money order on Brooklyn, Conn., registered letter or bank eheck, payable to my order. Remittances made in any other way are at the risk of the sender.

My Greenhouse facilities give me the best opportunity for constant tests of all seeds in my hands.

Market gardeners using large quantities of vegetable seeds and plants may be greatly benefited by sending me their list to be priced before buying elsewhere.

\section{Shipment of Plants.}

I will send plants by mail, as heretofore; but I would here impress upon my patrons the fact that larger'and finer plants, and more of them for the same amount, can be sent by express; extra plants are always included.

I MAKE NO CHARGE FOR BOXING OR PACKING. All orders should be addressed to WILLIAM R. THURBER, Brooklyn, Conn.

\section{Sowing Flower Seeds.}

In sowing all small seeds care should be taken to have the soil mellow and fine and the seeds should be covered very lightly-in fact the smallest of them should be sown and the soil merely pressed with a board or hand.

Hardy Annuals may be sown in the open ground from the time the ground is well settled in the spring till late in the summer for succession.

Half-Hardy Annuals should not be sown in open ground till after settled weather and biting frosts are past.

Tender Annuals must not be sown in open ground before all frost is past and the weather is warm and summer-like.

All Annuals may be forwarded early in hot beds or the window, but the best satisfaction results in open ground.

Biennials and perennials are best sown in shallow boxes and set out into pots or boxes; and flually, when strong, placed in permanent positions where they are to fiower. 


\section{General List of Flower Seeds.}

ANNUALS grow, bloom and die the first jear from seed.

BIENNIALS bloom the second year from seed and then die; though many if sown early in the spring will flower the first jear.

PERENNIALS bloom the second jear from seeds, and continue to grow and bloom for many jears.

ALL FLOWER SEEDS SENT FREE BY MAIL ON RECEIPT OF PRICE.

\section{ACROCLINIUM.}

One of the best everlastings, suitable for winter bouquets; half-hards annuals.

1 Mired, doable, 1 foot, pkt. je.

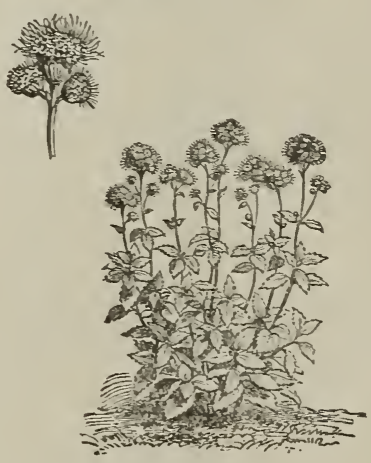

\section{AGERATUM.}

Very valuable for bouquets; lasting long in bloom. Halt-hardy annuals. Height, 3.4 foot.

2 Mixed. Dwart; blue and white ........................... jkt.

\section{ALYSSUM.}

Modest little plants for edging and border, its flowers being highly prized for bouquets.

3 Sweet. Pure white, very sweet, hardy annuals, 1 foot..per oz. $25 \mathrm{c}$.
4 Tom Thumb. This is one of the finest plants for edging and low beds. flowering for months; pure white; $1-2$ foot........... pkt. jc.

\section{AMARANTHUS.}

A class of plants ralued for their highly ornamented foliage; native of East Indies, requiring a poor, light soil to bring them to perfection, half hardy annuals.

J Tricolor. (Joseph's Coat). Red, rellow and green foliage..pkt. jc.

6 Salicifolius. (Fountain Plant.) Drooping, willow-shaped leares, tipped with orange, carmine and bronze................ pkt. $\bar{e}$.

\section{ANTIRRHINUM. \\ Snapdragon.}

The snapdragon or Antirrhinum is one of the most useful and showy border plants; halt hardy perennials.

7 'Tall Varieties Mixed. 2 feet. .................... pkt.

\section{GERMAN ASTER.}

This beautiful class of plants now constitutes one of our finest annual flowers. Plant the seeds early in hot beds or in pots or boxes, and transplant to a deep, rich soil six to trelre inches apart. 
8 Bettridge's Quilled. An improved form of Quilled Aster. The flowers are fine form and brilliant colors; 2 feet............ pkt. 5 c.

9 Giant Comet. Mixed colors. These beautiful Asters have long twisted petals formed into a loose. jet dense, half globe; flowers larye. .................... pkt. 10c.

10 Peony Flowercel Perfection Flowers large and double; choice mixed colors. 2 feet......pkt. 10c.

11 Victoria. Flowers very large, perfectly double, forming a compact bush; 2 feet high, choice mixed colors ................pkt. 10c.

\section{Vicks' Branching Snow} White. A most beautiful variety; flowers are very large.. pkt. 10c.

13 Dwar Pyramidal Bouquet. Height from 12 to 15 inches; a very free blooming variety; mixed coiors. ................ pkt. 10c.

14 Vicks' Branchùg. Superior to any other class of late flowering branching aster; mixed colors. 2 feet high.................pkt. 10c.

15 Vicks' Bramching Pink. A very beautiful variety; flowers large. ................ pkt. 10c.

16 Vichs' Banching Crimson. ................. pkt. 10c.

17 Ball-Shaped or "Jewel" Asters. The flowers are perfectly round or ball-shaped densely double, short, incurved petals. 2 feet; mixed colors................ pkt. 10e.

Col. of Asters as imported.

18 'Truffaut's Peoney Flowered Perfection. Twelve separate colors..................60.

19. Victoria. In twelve separate colors.................60e.

\section{BALSAMS.}

An old and popular favorite of which our present stock is a great improvement on old sorts, being usually double and finely colored and variegated, halfhardy annuals.

20 Double Camelia Flowered. Finest mixed colors, 2 feet. pkt. $5 \mathrm{c}$.

\section{Double White Perfection.}

22 Hose Flowered. Very double, mixed colors............ pkt. 5c.

Very fine, 2 feet .......pkt. 5c.

23 Mixed Balsam .....pkt. $5 \mathrm{c}$.

\section{BELLIS. Double Daisy.}

A well known perennial. They are admirable plants for making edging, etc. Half-hardy perennials.

24 Peremais. Extra fine, saved from named flowers; 1-4 feet..pkt. 10c.

\section{BROWALLIA.}

The Browallia is very pretty for bouquets. Half-hardy annuals.

25 Elata Major. Blue and white mixed................... pkt. $5 \mathrm{c}$.

\section{CACALIA. \\ Trassel clower.}

A beautiful annual, with a profusion of scarlet and orange tassel-shaped flowers, blooming from July to Oct. 26 Mixed. Yellow and scarlet.. ................... pkt. 5c.

\section{CALENDULA.}

A very showy, free-flowering genus or plants, producing a pretty effect in beds or borders. Hardy annuals. 27 LeProust. Nankeen colored 
28 IIeteor. Yellow with light orange striped flowers.....pkt. 5 c.

29 Pongei. Double white.pkt. 5c.

\section{CALLIOPSIS.}

A very showy border plant, producing flowers in shades of jellow, orange, crimson and brown. Tall varieties. Hardy annual; height 2 feet.

30 Mixed ............. . pkt. ǒc.

CANDYTUFT. Iberis.

Old popular and beautiful Hardy annuals.

31 White. Sweet scented. pkt. 5c.

32 Purple.......... " 5c.

33 Dark Crimson...... "

34 Fine Mixed ...... " 5 c.

\section{CANNA. Indian Shot.}

Extremely ornamental and stately foliage plants, producing a decidedly tropical appearance. Flowers bright and attractive. Half-hardy perennials.

3.5 Fremch Mixed........pkt. ว̌c.

CANTERBURY BELLS. Campanula Medium.

Well known and deservedly popular. Hardy perennials.

36 Single Mixed...... pkt. 5c.

37 Domble $" \ldots . . \quad$ " 5 c.

\section{CARNATION.}

A class of popular favorites, most of them deliciousiy fragrant, and with colors extremely rich and beautiful. Halfhardy perennials.

38 Marumerite. These are the most abundant bloomers of the carnat tion pinks. The flowers are of many shades of red, pink, white, variegated.

................. pkt. 5c.

39 Mixed. For border cultu're double.............. pkt. 10c.

\section{CELOSIA.}

These are exceedingiy brilliant and attractive, half-hardy annuals; never fail to please if grown from first qual. ity seed.

40 Pramidalis Mixed. 3 feet high... ............. pkt. 5e.

41 Crisiata Nana mixed..pkt. 5c.

t2 Plumosa Mixed.......pkt. 5c.

\section{CENTAUREA.}

Valuable silver foliage plants, very effective for baskets, vases and window boxes, as well as the finest silver leaved plants for contrasting with Coleus and other dark leaved plants, in massed beds, half-hardy perennials.

43 Gymmocarpa. Silver foliage

\section{1-2 fəet ............ pkt. 10c.}

\section{CHRYSANTHEMUMS.}

A well-known garden favorite. The annual varieties are among the most showy and effective of summer flowering plants.

44. Nixer. Annual varieties.... ..................... pkt. 5c.

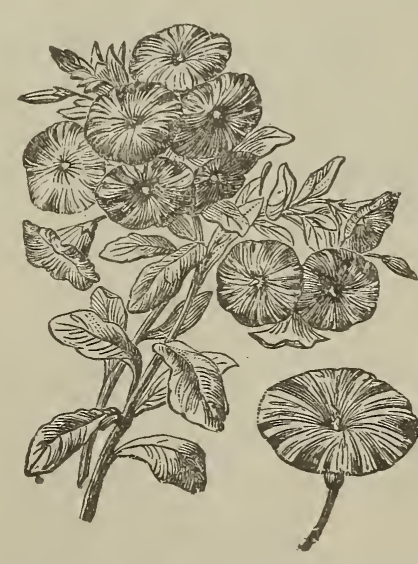

Mornimg Glory. 


\section{CONVOLVULUS.}

The most popular annual in cultiration, for in this is included the wellknown Morning Glory. The minor yarieties are well suited for bedding. They attain an average height of one foot. Half-hardy annuals.

45 Nonor Tricolor. Mixed..... .................... jkt.

46 MIIsor. (Morning Glory.) Mixed.

Per ounce, $10 \mathrm{c} . . . . . .$. . pkt. $5 \mathrm{c}$.

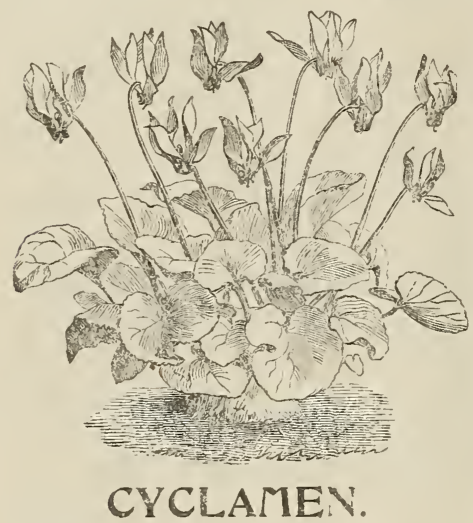

Beautiful winter and spring flowering plants. with sweet-scented, singular shaped flowers, for culture in potshalf-hardy perennials.

4i Cycramen Persicrms. Finest rarieties. Mixed........pkt. 10c.

\section{CYPRESS VINE.}

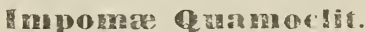

A tender climbing annual with graceful foliage; seeds should not be pianted in the ground before the last of Nay or the first of June.

ts virixed............. pkt.. כ̌c.

\section{DAHLIA.}

Seeds saved from the very finest named sorts in cultivation. Seed sown in early spring will produce plants that bloom from August until frost. Half-hardy perennials.

49 Double IIixed......pkt. 10c.

50 single " ...."

\section{DATURA. \\ Trumpet Flower.}

Hardy annuals, with double purple and white flowers; height 2 feet.

51 Datura Fastuosa. Mixed...

\section{DIGITALIS. \\ rox Glave}

A very hardy biennial, with flower stems at least 3 feet in height. bearing flowers of an irregular bell shape; color white and different shades of purple and red.

52 Fox Glave, Finest colors and shades mixed.............. pkt. 5c.

\section{DIANTHUS.}

A beautiful genus of easy culture, embracing some of the most popular flowers in cultivation. Their free blooming quality, together with the exquisite blending of colors and richness of single flowers, places them at the head of all bedding plants that are quickly grown from seed, Hardy annuals.

53 chimensis. Fine mixed double floweled.............. pkt. 5c.

5t aspeistis. Double Imperial pink, extra fine mixed. ...pkt jc.

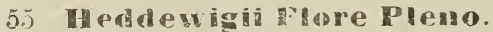

Double Japan pink, very showy, $1 \mathrm{ft}$. high ................. pkt. 5c.

56 Diarleataras. Dwarf of compact habit. Flower's very large of vavious colors; double.... . pkt. 5c. 
57 The Bride. Single large flower, white with violet center, pkt. 5c.

58 Eastern Queen. Beautifully marbled; single ...........pkt. 5c.

59 Crimson Belle. Rich crimson color ; flowers of very large size and substance; single. .............pkt. 5c.

60 All Kinds. Mixed........ 5c.

\section{ESCHSCHOLTZIA.}

\section{California Poproy.}

Extremely free-flowering and showy early annuals, of rich and beautiful (olors.

61 Finest Varieties. Mixed. ..................... pkt. 5c.

62 Doubled Mixed....... $5 \mathrm{c}$.

Eternal or Everlasting Flowers [See Helichrysum and Acroclinium.]

\section{GERANIUM. Pelargoniun.}

'These well known garden favorites arc as indispensable for indoer as for outdoor decoration, and should be extensively cultivated. Perennials.

63 Zomale. Finest mixed. pki. 10c.

\section{GILIA.}

Free-flowering hardy annuals, producing clusters of small, bright, delicate flowers; pretty in small clumps; flowers continually.

64 III Varieties. Mixed, pkt, 5c.

\section{GLOXINA.}

A superb genus of stove plants, producing in great profusion flowers of the richest and most beautiful hue; hot house bulbs.

65 Choree. Mixed. ....pkt. $20 \mathrm{c}$.

\section{GODETIA.}

All the varieties of the Godetia are well worth growing. The profuseness of bloom and delicate tints of color have rendered them unisersal favorites. 66 Fine Mixed. All colors. pkt. 5́c.

\section{GOURD. \\ Mock Orange.}

Rapid growing plants, useful for covering unsightly spots, producing beautiful and often very curious many shaped fruits.

67 Gourds. A splendid assortment of best varieties.......... pkt. $5 \mathrm{c}$.

\section{GYPSOPHILA.}

Elegant little plant, adapted for work baskets or edgings.

68 Murallis. A charming little plant, covered with pretty little pink flowers; hardy annuals... .. pkt.5c.

\section{HELIANTHUS.}

Sunflower.

Very handsome varieties of sunflower, remarkable for their stately growth and the brilliancy and size of their flowers.

69 Californicus. Extra large and double; 5 feet high........pkt. 5 c.

\section{HELICHRYSUM.}

Eternal Flower.

An effective and indispensable everlasting flower, both for garden, ornamental and winter bouquets; hardy annuals.

70 Finest Color's. Mixed. pkt. $5 \mathrm{c}$.

\section{HOLLYHOCK.}

()ur seed of this favorite has been saved srom an unsurpassed collection of the most rich and brilliant colors; hardy perennials.

71 Hollyhock. Extra choice; double, of great beauty; splendid English varieties mixed...pkt. 10c. 


\section{LARKSPUR.}

Beautiful and well known plants of the easiest culture; useful for cutting hardy annuals.

72 Dwarf Rocket... Finest mixed, double... ............. ... pkt. 5c.

73 Tall Rocket. Finest mixed, double.............. pkt. $5 \mathrm{c}$.

\section{LINUM.}

Neat and beautiful half-hardy annual with bright and handsome flowers all summer, produced in abundance.

74 Grandiflorum Rubrum. bright crimson; 18 inches....pkt. 5c.

\section{LOBELIA.}

A class of plants of great beauty and usefulness; equally well adapted for pots, baskets, vases or for border culture; half-hardy annuals.

7 Crystal Palace Campacta.

A beautiful variety........pkt.5c.

76 Speciosa. The most effective of

Lobelias, trailing .........pkt. 5̃c.

77 Blue King Dark blue, white certre................. pkt.5c.

78 Erinus. Mixed.........pkt. 5c.

\section{MAURANDIA.}

A beautifnl, rather delicate and graceful climber, with flowers blue, white and mauve, of various shades.

79 Finest Mixed.........pkt. 10c.

\section{MARIGOLD.}

The French and African Marigold are among the most elegant and beautiful of our annuals; half-hardy annuals.

80 African Quilled. Finest doub-

le 1 foot high........... pkt. 5c.

81 French Duvarf. Mixed double;

1 foot high..............pkt. 5c.

82 French Striped. Striped gold ....................... pkt. כूc.

\section{MARVEL OF PERU}

The well known "Evening Beauty." "Four O'clock," "Bell of the night. etc., of varied colors and striped; very tragrant and free-flowering.

83 Jalapa. Finest mixed, including beautiful striped sorts........pkt. $5 \mathrm{c}$.

\section{MIGNONETTE.}

A well known favorite. highly esteemed for its fragrance; hardy annuads. 84 Nignonette. (Reseda Oderata.) per ounce. $10 \mathrm{c} . . . . . . . .$. pkt. $5 \mathrm{c}$.

85 Hybrid Spiral. This variety of Mignonette is a strong grower and fragrant ..................

86 Golden Queen. Literally a mass of fragrant gold .....pkt. 5c.

\section{MIMOSA.}

87 Pudica. A curious and interesting plant, the leaves (losing if touched or shaken, but opening again; half-hardy annuals... .... pkt. 5c

\section{MORNING GLORY.}

88 Japan Moruiug Glory. One of our most beautiful climbers. The flowers are of gigantic size; they attain a height of from 30 to 50 feet. Mixed colors............pkt. 10c.

\section{MIMUULUS. \\ Moukey Fiower.}

Very striking and beautiful, tender looking plants, excellent for pots, boxes, baskets and open ground culture.

89 Voschatus. (Musk Plant.) Yellow; 1-2 foot high......pkt. 5c.

90 Choice Mixed. Finest spotted sort............... pkt. ǰc.

\section{MYOSOTIS. \\ Foryet-Me-Not.}

The different species of this popular genus are all very beautiful. Theysucceed best in moist places.

91 Disitistora. Large, sky-blue flowers; very early and free-blooming .................... 
92 Semperforens. Flowering from early spring till autumn; white, 6 inches ................. 10kt.

\section{NASTURTIUMS.}

For covering lattice-work and trelises, old stumps, etc., the tall nasturtiums are adapted. The dwarf nusturtiums are excellent for bedding, forming beautifully rounded clumps, covered with showy flowers.

93 Luteum. Rich jellow, no blotch. es ............ 10c, pkt. 5c.

94 Schillingi. Yellow maroon blotches............ oz. 10c, pkt. 5c.

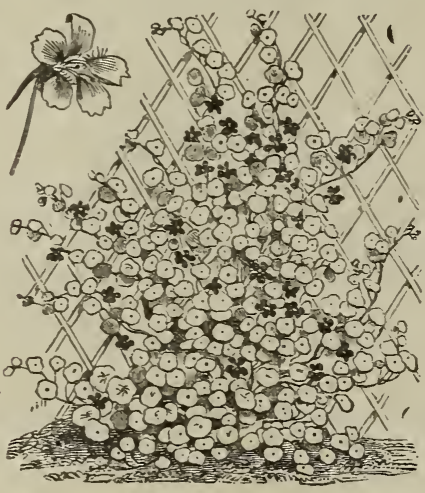

Tall Rose. oz. 10c....pkt. jc.

“ Creany White. oz. 10c ..................pkt. 5c.

97 “ Scarlet. oz. 10c.pkt. 5̃c.

98 “ Orange. oz. 10c.pkt. 5c.

99 " Crimson. oz. 10c pkt. óc.

100 Maroon. oz. 10c... ..pkt. je.

101 Tall Mixed. $10 \mathrm{ft} .0 \mathrm{z} .10 \mathrm{c}, 1-4$ lb. $30 \mathrm{c} \ldots \ldots \ldots \ldots \ldots$........... 5 c.

102 Empress of India. Dark foliage ; flowers crimson, dwarf. $\mathrm{Oz}$. $1 \tilde{c} \ldots \ldots \ldots \ldots \ldots \ldots \ldots$.......

103 Tom Thumb. Orange, $15 \mathrm{c}, 5 \mathrm{c}$.

$10 t$ “ "“ Scarlet, 15c, 5c.

105 “ “ “ White, 15c, 5c.

106 ، “ Maroon, 15c, jc.

107 Luteum. Light yellow, no blotches.............15c, $5 \mathrm{c}$.
108 Golden King. Golden Maroon blotches............... כ̃c.

109. Dunnett's Spotted. .. 15̃c, こ̃c. 110 Tom Thumb. Mixed, 1 foot $1-t$ pound $35 \mathrm{c} \ldots \ldots \ldots \ldots . . .10 \mathrm{c}$, o.c.

\section{PANSY. \\ Viola Tricola.}

The pansy is a general favorite. The flowers are in the greatest perfection in May or June. Seeds sown in August in the open border will come up readily in a few weeks. They require to be covered during the winter with evergreen boughs or a cold frame. If sown early in spring they will bloom the first season. Hardy perennials.

111 English. Extra select; large flowers..................

112 Giant Trimardeau. Mixed colors................... 10 c.

113 Odier and Cassiers. Very large flowers and distinctively blotched, mixed colors.......... pkt. 1 je.

114 Emmeror William. New brilliant ultramarine blue, with riolet eye.................. pkt. j̃c.

115 King of the Blacks. Almost coal biack; true to seed....pkt. $5 \mathrm{c}$.

116 White. Snowflake; choice for cemeter厂 use........... .pkt. כ̌c.

117 Yellow. Constant and fine 118 ....................... pkt.

Mixed. Fine quality...." $10 \mathrm{c}$

119 Good Mixed..........

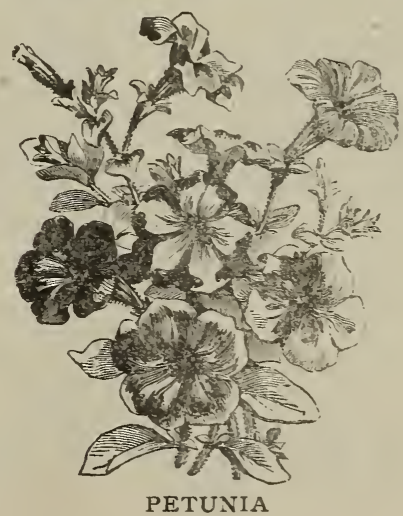




\section{PETUNIA.}

Profuse blooming, extremely showy and indispensable garden favorites; half-hardy annuals.

120 Petunia Hybrida. Large flowering, single, fringed, mixed. ..................pkt, 20 .

121 Petunia. Single mixed. ..................... pkt. 5c.

\section{PHLOX DRUMMONDI.}

This genus of plants is unrivalled for richness and brilliancy of color, profusion and duration of blooming. Hardy annuals.

122 Star Shaped Phlox. Regular star-shaped form..........pkt. 5c.

123 Double Mixed......." 10c.

124 Alba Flore. Pure white.

\section{Grandfora Splendens.}

l.arge flowers, mixed......pkt. 5c.

126 Coccinea. Deep scarlet.

…...............

127 Mixed. First quality..pkt. 5c.

\section{POPPY.}

A tribe of remarkably showy, freeflowering plants, growing freely in any soil ; hardy annuals.

128 Peony Flowered. Mixed double..............pkt. 5c.

129 Unbroswm. Color a rich vermillion, with black spots on each petal................ pkt. 5c.

130 Damebrog. New and large, a bright scarlet ..........pkt. 5c.

131 retip Poppy. A magnificent new species, resembling scarlet tulips............... pkt. 5c.

132 Single IIixed....... pkt. 5c.

133 Tceland Single IIIxed.

The lovely white, yellow and orange red flowers are in bloom from early summer until fall. Hardy perennials, blooming the first year from seed. ..................... pkt. 10c.

\section{PORTULACCA.}

In praise of these charming flowers it is impossible to speak too highly, Hardy annuals.
134 Gramdiflora. Finest mixed, double ............ pkt. 10c.

135 Splendid. Single, mixed, all colors.................pkt. $5 \mathrm{c}$.

\section{PRIMULA. \\ Chinese Primrose.}

Profuse-flowering plants, indispensable for winter and spring decorations in the conservatory; succeed best in sandy loam and leaf mould; tender perennials.

136 Sinensis Fimbriata. Single iringed; mixed colors... pkt. 20c.

137 Sinensis Fimbriata. Single, fringed; pure white......pkt. 25e.

138 Sinfusls Finbriata. Single, fringed; red............pkt. $25 \mathrm{e}$

\section{RICINUS. Castor Oil Bean.}

Stately, ornamental plants of elegant foliage; splendid as single plant on large lawns; hardy annuals.

139 Ricinns.Mixed varieties. pkt.5c.

\section{SALPIGLOSSIS.}

Very ornamental and useful plants for late summer and autumn decorations; half-hardy annuals.

140 Large Flowered. Finest mixed extra...........pkt. 5e.

\section{SALVIA. \\ Sage.}

Magnificent bedding plants producing large spikes of bloom from July until frost; half-hardy perennials.

141 Splemdens Brilliant scarlet .................. pkt. $5 \mathrm{c}$.

SCABIOSA or Mourning Bride.

\section{Sweet Scabiosa}

Handsome showy plants for mixed borders, flowers beautifully variegated, hardy annuals.

142 A1mopurpurea Major. Finest double; mixed ............pkt. 5c. 143 Dwarf. Duuble mixed pkt. 5c. 
STOCKS. Ten Wceks.

\section{Irathiola.}

Especially valuable on account of their long flowering period and bright, constant flowers produced in abundance.

144 Finest Thed. Dwarf German.

.................. . . 5kt.

145 Lange Flowering. Finest mixed.............. pkt. $5 \mathrm{c}$.

140 Cut find Come Agañ. Pure white............... pkt. 10c.

147 Pure White..........pkt.ōc.

148 Dwarf Pyramidal. Best stock in cultiration. Mixed plt. je.

149 Wallifower Leaved, Finest dwarf mixed.............pkt. §̌c.

\section{SWEET WILLIAM. \\ Diamthus Barbatis.}

A vers beautiful and well known class of plants, of extreme richness and dirersity of color. Hardy pereunials.

150) Single Vixed .......pkt. ǰc.

151 Double Flowerisg. Finest mixed from a splendid collection of double flowers...........pkt. ふ̌c,

\section{THUNBERGIA.}

Pretty climber of slender rapid growth with gay and justly admired flowers, tender annuals.

152 Finest Mixed. buff, white, orange, etc ..........pkt. sc.

\section{SWEET PEAS.}

\section{Lashyrus.}

The sweet peas are among the most popular annuals that enrich the garden; they may be planted and trained on sticks the same as the common peas.

1.53 Borbatton Marosn. oz. Se. ... ................. . pkt. jc.

$15 t$ Blanche Ferry. pink and white, ............... $\ldots \ldots \ldots \ldots \ldots \ldots \ldots \ldots \ldots$ pkt.jc

155 Emily Irendersou Thite. oz $8 \mathrm{c} . \ldots \ldots \ldots \ldots \ldots \ldots$....... je. 156 Striped. Red, white, oz. Sc.
157 Invincible Scarlet. Bright scarlet ind fringed, oz 8c..............pkt. Je.

1 s Vesuvius. Spotted maroon, oz. 8c.....................................pkt. 5̌. 159 Butterfly. Wbite laced with blue; fragraut, oz. Sc............pkt. 5c. 160 Princess Beatrice. Rose color, oz. Sc.

$16 \mathrm{l}$ Fairy Queen. II bite and pink.

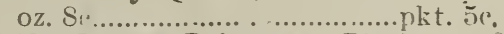
162 Crown Princess. Blush, oz. \&e.

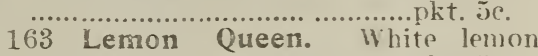
tinted, oz Sc....................... plkt. ¿̌ce.

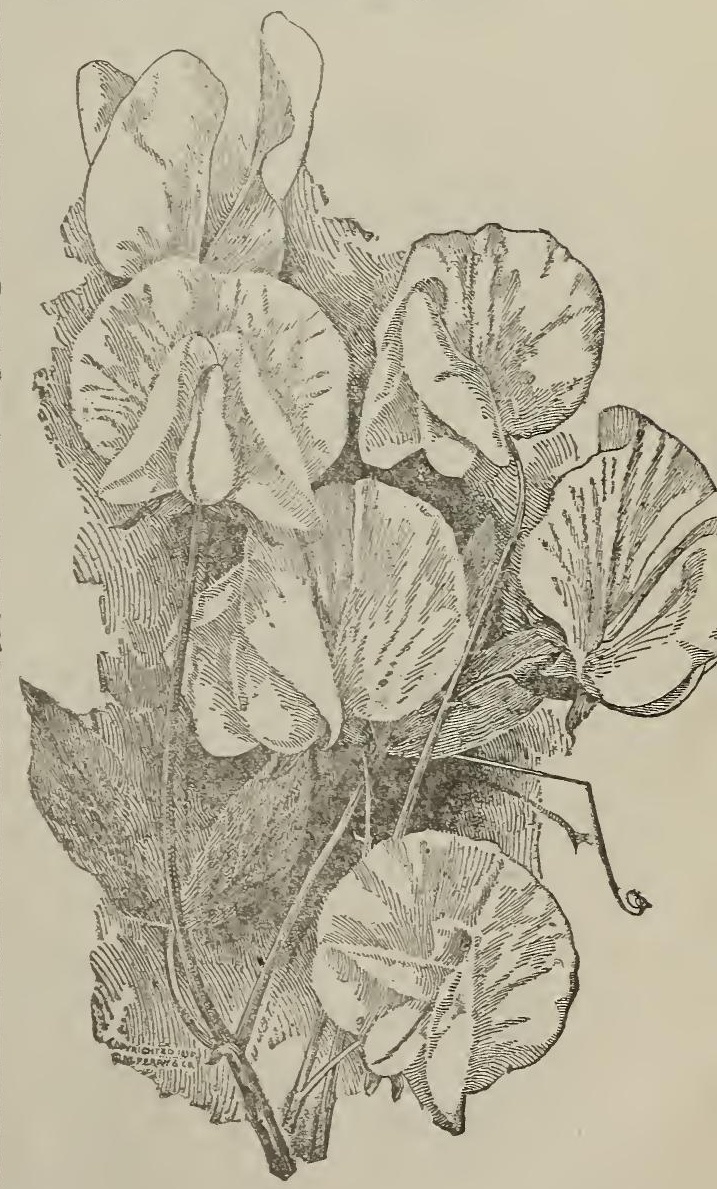


164 Katherine Tracy. Soit pipk, oz,

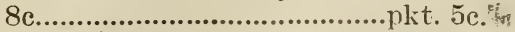
165 Splendour. Rose and crimson, oz. 8c................................pkt, 5c.

166 Lottie Eckford. White edged blue, oz. 8c.........................pkt. 5e.

167 Firefly. Crimson Scarlet, oz. 8c. pkt. 5c.

168 Mixed. 1lb. 60c. 1-4 lb. 20c. oz.

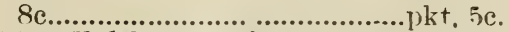

169 Eckford's Mixed. Large flowers, per lb. 60c. $1-4$ lb. 20c. oz. 8c. 170 Fifteen Varieties..................50c.

\section{VERBENA.}

A charming genus of universalls admired and easily cultivated plants, simply requiring the treat- ment of half-hardy annuals to have them bloom during the summer. Tender perennials.

171 Hybrida, From the finest named sorts, extra mixed...............pkt. 15c. 172 Fine Mixed.........................pt. 10c.

\section{WHITLAVIA}

Very pretty free flowering hards annuals, producing exquisite bell-shaped flowers, easily cultivated.

173 Mixed. Blne and white, pkt. sc.

\section{ZINNIA.}

Extremely showy late summer and autumn flowering plants of great richness and variety of eolor's.

174 Elegans, Double, mixed...pkt. ise

175 Eight Varieties............pkt. 30c. 


\title{
SPECIAL LIST
}

\section{OF \\ VEGETABLE SEEDS}

EMBRACING

\author{
All the Leading Varieties. \\ Suited to the Wants of the Market Gardener \\ as well as the Family Gardener.
}

Of course, we canuot warraut them to produce a perfect crop, as we do not Lave control of their planting nor the culture of the crops, and often the weither is so unfavorable as to either destroy the best seeds or to badly injure a growing erop.

When vegetable seeds are ordered by freight or express in quantities of onehalf pound and upward, they will be sent at catalcgue prices, but when ordered by mail in the same quantities, add at the rate of eight cents per pound for postage.

When Beaus or Pean are ordered by mail by the quart or pint, add at the rate of fifteen cents per quart. Corn, add at the rate of ten cents per quart.

\section{BEANS.}

Dwarf or Bush.

roc. per packet by mail. Add $15 \mathrm{c}$. per quart if sent by mail.

Innproved Eanly reed Valenine. Early, productive, tender and of best quality, green pod. $\mathrm{Pt}, 12 \mathrm{c}$, qt., 20), $p k$., $\$ 1.25$.

Dovarf Honticuliural. A bush variety of the well knowin Horticultural Pole beitn. 1't., 15c, qt., 20c., uk.. \$1 2.5.

Davis WInite Wax. Variety with wax-like pods. The seeds are pure white. It is very productive aud an excellent variety. Pt. 15̌c., qt , $25 \%$. pk. \$1.75

Improved Muntless Goldeu Wax. The pols are produced i i. profusion, are quite stringless, very white wax-like. Pt. $15 \mathrm{c}, \mathrm{qt}, 25 \mathrm{c}$. pk, $\$ 1.75$.
Wardwell's Dwarf Kidney Wax. This variety is very hardy. It produces a heavy crop of purely wax pods. not liable to rust or blister. The pcds are thick and tender. Pt. $15 \mathrm{c}, \mathrm{qt} .25 \mathrm{c}, \mathrm{pk}$. $\$ 1.75$

Burpee's Sringless Green Pod. The pods are thick, crisp and tender. It is of value to the market gardener, being very early. Pt. $15 \mathrm{c}, \mathrm{qt}, 25 \mathrm{c}$, pk. $\$ 1.2 \tilde{\text {. }}$

Hendersou's Bush Lima. It $g$ rows in a compact bush form about 18 inches high, and produce enormous crops of delicious beans. Pt, $15 \mathrm{c}, \mathrm{qt} .30 \mathrm{c}$.

Barpee's Bush Lima. This is a bush form of the well known large IVhite Lima Bean. It is very hxed in its bush character, growing to a uniform height of about 20 inches. The pods contain as many beans as the Pole Lima. Pt. 20c, qt, $30 \mathrm{c}$. 


\section{BEANS.}

\section{Pole or running.}

Ioc. per packet by mail. Add 15c. per quart if sent by meil.

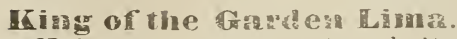

Universally grown for shell beans, dry or green. Qt. $30 c$, pt. $20 \mathrm{c}$.

Obl Homesiestl. The pods are solid, meaty, stringless when young and of fine quality. Qt. 25c, pt. $15 \mathrm{c}$.

\section{Jensey Extra Early Linha.}

The Jersey Extra Early conubines quantity, quality and earliness, Qt. $30 \mathrm{c}$, pt. $20 \mathrm{c}$.

\section{Honticultural or Speckled Cran-} berry, Excellent for use, green or dry. Qt. 25c, pt, 15 c.

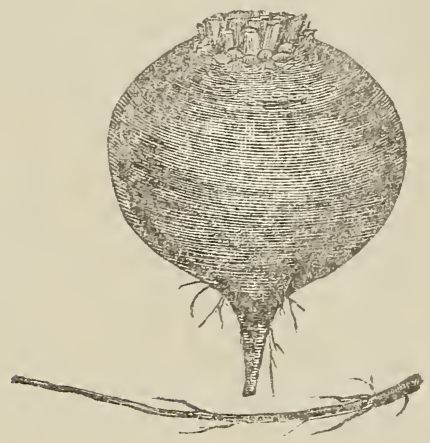

\section{BEETS.}

If by mail in quantities of one-half pound and upward, add at the rate of $8 \mathrm{c}$. per $1 \mathrm{~b}$.

The soil should be rich, deep and mellow; plant the seeds in rows 12 or 15 inches apart.

\section{Edunands' Early Trentip.}

Small top, smooth and round, good size, dark red, sweet and tender. Pkt. 5c, oz. 10c, 1-4 lb, 15c, 1b. 50c. foot to 18 inches.

\section{Lomgsmooth Blood Red.}

An excellent late variety. Pkt. כ̌c, oz. $10 \mathrm{c}, 1.4 \mathrm{lb}, 15 \mathrm{c}, 1 \mathrm{~b}, 45 \mathrm{c}$.

Croshy's Egyptian Beet. Earliest in cultivation. Pkt j̄c, oz, 10c, 1-4 1b. $20 \mathrm{c}$, 1b. $50 \mathrm{c}$.

Eclinse Beet. Fine quality; round, dark crimson. Pkt. 5c, oz. 10c, 1-t ib. $20 \mathrm{c}, 1 \mathrm{~b} .50 \mathrm{c}$.

Eariy rosoogl Turnip. The standard early sort; a late keeper. Pkt. 5c, oz. 10c, 1-4 lb. 15̃c, lb. t5̃c.

Cuimson Globe. Dark red flesh, very tender and sweet; early. Pkt. 5c, oz. 10c, 1-4 lb. 20c, 1b. 60c.

Swiss Chard, or Sea Kale Beet. This variety is grown for its leaves, which are used for greens. Pkt. 5c, oz, 10z, 1-4 lb. $15 \mathrm{c}, 1 \mathrm{~b} .40 \mathrm{c}$.

Dewing's B lood Turmip. Deep blood red, fine form and flavor; good market sort. Pkt. 5̃c, oz. 10c, 1-t lb. $15 \mathrm{c}, 1 \mathrm{~b} .50 \mathrm{c}$.

\section{Varieties Adapted to Growing} for Feeding Stock. Sow in April and May, 6 to 8 pounds to an acre.

Champion Yellow Globe. Smooth globe shaped roots, of large size and excellent quality. Oz. 8c., 1-4 lb. 10c., lb. $30 \mathrm{c}$.

Norbition Giant Long Red Miangel. A sreat improvement on the commou Long Red, producing immense crops ou good soil. Oz, Sc, 1-4 lb. 10c, lb. 30c.

\section{CABBAGE.}

If by mail in quantities of one-half pound and upward, add at the rate of $8 \mathrm{c}$. per $\mathbf{l b}$.

The cabbage requires a deep, rich soil and thorough working. For early use the plants should be started in a hot bed or cold frame. Some of the large, late varieties seem to do best if the seed is sown in hilis where they are to remain. Plant the large varieties feet apart, the small, early sort from a

\section{Pkts. Vegetable Seeds for $\$ 1.00$.}


Henderson's Early Suminer. It is the earliest of large cabbage, ten days later than the Wakefield, and rarely, if ever, cracking open when ripe. Pkt. 5c, oz. $15 \mathrm{c}, 1-41 \mathrm{~b} .50 \mathrm{c}, \mathrm{lb}$. $\$ 1.75$.

Early Spring. A round, flat-headed cabbage, asjearly as Jersey Wakefield. Pkt. 5c, oz. 20c, 1-4 lb. 60c, lb. $\$ 2.00$.

Henderson's Succession. About one week later than the Early Summer, but is double the size; good either early or late. Pkt. 5c, oz. 20c, $1-4$ lb. 60 c, lb. $\$ 2.00$.

Early Jersey $W$ akefield. Lead-

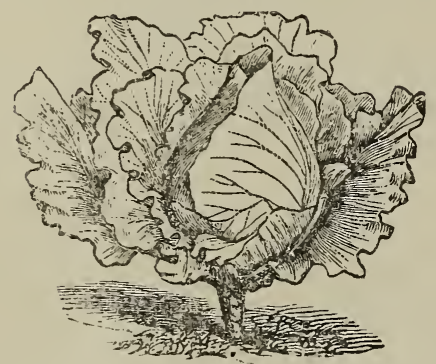

ing early market variety. The best and most profitable sort. Pkt. 5c, oz. $20 \mathrm{c}, 1- \pm 1 \mathrm{~b} .60 \mathrm{c}, 1 \mathrm{~b} . \$ 2.00$.

Early Wimmingstadt. An excellent variety of good size; sure to head even in poor soil. Pkt. je, oz. $15 \mathrm{c}, 1-4$ lb. $50 \mathrm{c}, 1 \mathrm{~b} . \$ 150$.

Damisl Ball Mead. A wintervariety, head round, hard and tender. Pk1. 5̃c, oz. 20c, 1-t lb. 6ãc, lb. $\$ 200$.

Large Lare Drumhera. Very large size; sound compact heads. Pkt. joc. oz. 15c, 1-t lb. $40 \mathrm{c}, 1 \mathrm{~b} . \$ 1.50$.

Portler's Improved Brunswick. An excellent second early and late variety. Plst. j̇, oz. $15 \mathrm{c}, 1-4 \mathrm{lb} .50 \mathrm{c}$, 1b. $\$ 1.75$.

Sione Mason. Large compact and of fine quality; late, good keeper. Pkt. 5c, oz. 15c, 1-4 lb. $40 \mathrm{c}, 1 \mathrm{~b} . \$ 1.50$.

Preaniun Mat Datcils. A superior variety: large, of excellent flavor.

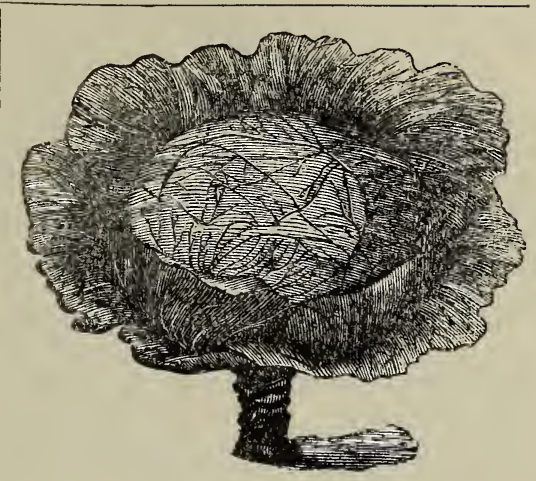

Pkt. 5c, oz. 15c, 1-4 lb. 40c, lb. $\$ 1.50$.

A utuma King. The finest late cabbage. Pkt. 5c, oz. 20c, 1-4 lb. $60 \mathrm{c}$, lb. $\$ 2.00$.

Red Dutch. Excellent for pickling. Pkt. 5c, oz. 20c, 1-4 lb. 60c, lb. $\$ 2.00$.

\section{CARROTS.}

If by mail in quantities of one-half pound and upward, add at the rate of $8 \mathrm{c}$. per $1 \mathrm{~b}$.

Danvers. Haif Long. Stump Ronted. A valuable sort; rich shade of orange. Smooth. Pkt. 5c, oz. $10 \mathrm{c}, 1-4 \mathrm{lb} .25 \mathrm{c}, 1 \mathrm{~b} .70 \mathrm{c}$.

Long Orange. large size; good for garden and field culture. Pkt. 5 c, oz. 10 e, 1-4 lb. 20c, 1b. 65 c.

Chantenay. A stump rooted sort; smooth, and o: a rich orange color. Pkt. 5̃c, oz. 10c, 1-4 lb. 25c, 1b. 70c.

\section{CAULIFLOWER.}

Any soil that will grow early cabbage will grow cauliflower, as their requirements are almost similar.

\section{Henderson's Early Snowball.} This variety has given the greatest satisfaction in all sections; the earliest of Cauliflowers. It is about a week earlier than any other sort. Every plant forms a head. Pkt. 15c, oz. $\$ 2.00$. 25 Pkts. Vegetable Seeds for \$I.00. 


\section{CELERY.}

Sow seeds in a hot bed or in a cold frame. As soon as the plants are about three inches high, transplant to a nicely prepared bed in the border, setting them four or five inches apart. When some eight inches high and fine, stocky plants, set them in trenches. Earth up a little during the summer, keeping the leaf stocks closely together. so that the soil cannot get between them. Finish earthing up in autumn, and never hoe or earth up in moist weather. nor when plants are moistened with dew.

White Plume. The one quality recommends it especially above other sorts is that it can be blanched without high banking. Pkt. $5 \mathrm{c}, \mathrm{nz} 20 \mathrm{c}$.

Goldew Selfolanclung. A mos $r$ valuabie variety, partaking of the character of the celebrated White Plume, golden color, very solid and of a nut'y flavur. Pkt. 5c, oz. 30c.

Hendersoa's Haif Dwant. One of the best large varieties in cultiva, tion. Pkt. 5c, oz. $20 \mathrm{c}$.

\section{CORN.}

10c. per packet by mail. Add roc. per quart if sent by mail.

Irickox Hybarid. It is one or two weeks earlier than Stowell's Evergreen, makes a large ear of very white and handsome grain. Pt. 10c, qt. $15 \mathrm{c}$, pk. $\$ 1.00$.

Cory Eandy Sweer. It is the earliest of the large red cob varieties. $\mathrm{Pt}$. $10 \mathrm{c}$, qt. $15 \mathrm{c}$, pk. $\$ 1.00$.

White colb Cory. An extra early variety, identical with Cory Early, except in color. Pt. $10 \mathrm{c}$, qt. $15 \mathrm{c}$, pk. $\$ 1.00$.

Early Preno. A fine white, extra early corn. Pt. 15c, qt. 25c.

First of A11. Resembles Cory, but earlier. Pt. 10c, qt. 20c.
Moone's Eaniy Concord. A delicate variety; productive. Pt. $10 \mathrm{c}$, qt. $15 \mathrm{c}, \mathrm{pk} . \$ 1.00$

Sinwell's Everuber. The favoritr. Very tender and excellent for the table. Pt. $10 \mathrm{c}$, qt. $15 \mathrm{c}, \mathrm{pk} . \$ 1.00$.

Porter's rixcelsion. The sweetest medium early sweet corn, twelve rowed white prolific. Excellent for canning. Pt. $10 \mathrm{c}$, qt $15 \mathrm{c}, \mathrm{pk} . \$ 1.00$

Perry's Hy lorid. Stocks of medium height bearing two large twelve or fourteen rowed ears, cookiug very white and tender. Pt. 10c, qt. $15 \mathrm{c}$, pk. $\$ 1.00$.

Crosby's Early. Early and a great farorite. Rather small ears but productive and excellent quality. Pt. $10 \mathrm{c}, \mathrm{qt} .15 \mathrm{c}, \mathrm{pk}$. $\$ 1.00$.

\section{CUCUMBER.}

If by mail in quantities of one=half pound and upward, add at the rate of $8 \mathrm{c}$. per $\mathrm{lb}$.

In this latitude, it is useless to plant in the open ground until near the first of June. Make rich hills of well rotted manure, two feet in dirmeter, and plant dozen or more seeds, covering half an inch deep. When ali disnger. from insects is over, pull all but three or four of the strongest plants. The middle of June is early enough to plant for pickling, make the hills 6 feet apart.

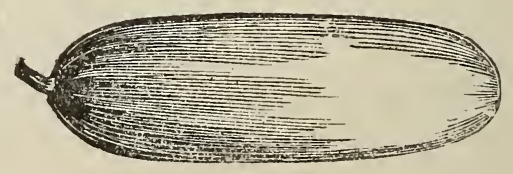

Innpoved Early Whire Spime. A favorite market variety; productive; pkt. ǰc, oz, $10 \mathrm{c}, 1 .+1 \mathrm{~b} .25 \mathrm{c}$, lb. $65 \mathrm{c}$.

25 Pkts. Vegetable Seeds for \$1.00. 
Early Cluster. An esteemed early variety ; growing in clusters; productive. Pkt. 5c, oz. 10c, 1-4 lb. 25c, lb. 65̃c.

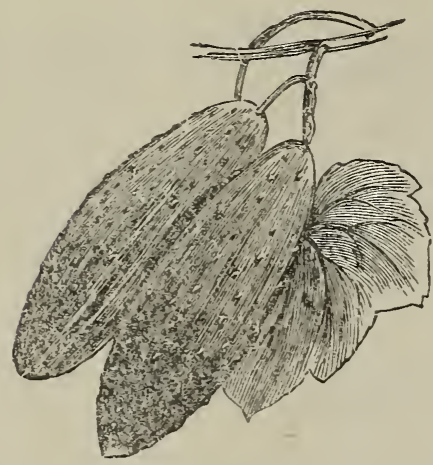

Green Prolific. As a picking rariety is unsurpassed. Pkt. jo, oz. $10 \mathrm{c}, 1- \pm 1 \mathrm{lb} .25 \mathrm{c}, 1 \mathrm{~b} 65 \mathrm{c}$.

Nichol's Medium Green. It is straight and smooth, the Hesh tender and crisp. Pkt. óc, oz. 10c, 1-4 lb. $25 \mathrm{c}, 1 \mathrm{~b} .65 \mathrm{c}$.

Long Green. Produces long fruit of superior quality: firm and crisp. Pkt. 5c, oz. 10c, 1-4 lb. $25 \mathrm{c}, 1 \mathrm{~b} .65 \mathrm{c}$.

Early Russian. Very early, fruit grows in pairs: hardy and productive. Pkt. $う \mathrm{c}, \mathrm{oz} .10 \mathrm{c}, 1-4 \mathrm{lb} .25 \mathrm{c}, \mathrm{lb}$ 650 .

Early Frame. An old popular variety, excellent for pickles when small. Pkt. 5c, oz. 10c, 1-4 lb. 25cc, lb. $65 \mathrm{c}$.

Bosion Pickling. For pickling. Pkt. 5e, oz. 1ue, 1-4 lb. 25c, 1b. 65̃ c.

\section{EGG PLANT.}

'The egg plant is tender and raquires to be started very early under glass.

New York Imuproved. The leading variety. Pkt. 5c.

\section{LETTUCE.}

lettuce needs a moist, rich soil, rapid growth makes better quality.

Early Curled Simpson. Leading market varieties. Pkt. 5c, oz. 10c, 1-4 lb. 30c, lb. \$1.00.

Salamander. The best variety for summer use, forming good sized heads; color, light green on outside, white on inside; stands the drought well. Pkt. 5c, oz. 10c, 1-4 lb. 30c, lb. $\$ 1.00$

Early Prize Head. The leaves are crisp and tender, and remain so throughout the season. Pkt. je, oz. $10 \mathrm{c}, 1-4$ lb. $30 \mathrm{c}, 1 \mathrm{~b} . \$ 1.00$.

Grand Rapids. As a lettuce for greenhouse forcing this variety stands at the head of the list, being of quick growth. Pkt. 5c, (1z. 10) $1-4 \mathrm{lb} .30 \mathrm{c}$. Ib. $\$ 1.00$.

Hanson. Outer leares green, inner leaves white. makes large heads. Pkt. 5c, oz. 10c, 1-4 lb.30e,1b. \$1.00.

\section{MELONS, MUSK.}

If by mail in quantities of one=half pound and upward, add at the rate of $8 \mathrm{c}$. perlb. Nelons thrive best in a moderately rich soil.

Emerald Geun. This variety is of rich, delicious flavor and fine quality; very early and prolific; skin of a deep emerald green. The flesh is thick. salmon colnr. Pkt. 5c, oz. 1.0c, 1.4 lb. $25 \mathrm{c}, 1 \mathrm{~b} .75 \mathrm{c}$.

Nutueg. Skin deep green, the flesh a greenish rellow, rich and sugary. Pkt. 5c, oz. $10 \mathrm{c}, 1-4 \mathrm{lb} .25 \mathrm{c}, 1 \mathrm{~b} .75 \mathrm{c}$.

Early Hackensack. The popular variety of Musk Melon; very early, attain a good size, is of delicious flavor and wonderfully productive. Pkt. ว́, oz. 10c, 1-4 lb. 25c, lb. $75 \mathrm{c}$.

Milles"s cream. Large, productive, jellow flesh. Pkt. 5́c, oz. 10c, 1-4 lb. 25̃c, 1b. $75 \mathrm{c}$. 


\section{MELONS, WATER.}

Mountaiu Sweer. Fruit oblong, dark green, rind thin, flesh red, solid and very sweet. Pkt. 5c, oz. 10c, 1-4 lb. 25c, lb. 65c.

Phinney's Early. Flesh red, good quality, early and productive. Pkt. $5 \mathrm{c},{ }^{\mathrm{z}}$. 10c, $1-4 \mathrm{lb} .25 \mathrm{c}, 1 \mathrm{~b} .65 \mathrm{c}$.

Cole's Early. The finest watermelon for the amateur, a sure cropper, enormously prolific, flesh bright red

in color, and the rind is thin and brittle. Pkt. 5c, oz. 10c., 1-4 lb. 25c, lb. $65 \mathrm{c}$.

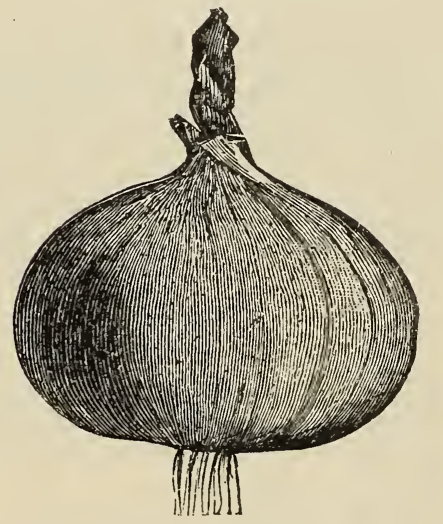

ONIONS.

If by mail in quantities of one-half pound and upward, add at the rate of $8 \mathrm{c}$. per $\mathrm{lb}$.

The onion thrives best in a rather deep, rich, loamy soil, and unlike most vegetables, succeeds well when cultivated on the same ground for successive years. The ground should be manured the previous autumn, and laid up in ridges during the winter to soften. As early in the spring as the ground is in working order commence operations by leveling the ground with a rake; tread it firmly. Take care nnt to stir the soil too deeply, or to collect it about the growing bulbs.
Southport Vellow Globe. A handsome globular onion, of mild flavor and a good keeper. Pkt. 5c, oz. 20c, 1-4 lb. 70c, lb. \$2.25.

Southport White Globe. Handsome globular onion, of a mild flavor, one of the best. Pkt. 5c, oz. 30c, 1-4 lb. $\$ 1.00,1 b . \$ 350$.

Yellow Globe Danvers. An excellent variety. mild flavor and very productive. Ripens early and is a good keeper. Pkt. 5c, oz. 20, 1-4 lb. $75 \mathrm{c}, \mathrm{lb} . \$ 2.25$.

Early Red Fla1. Extra early, dark red. Pkt. 5c, oz. $15 \mathrm{c}, 1-4 \mathrm{lb} .50 \mathrm{c}$, lb. $\$ 160$.

Werhersfield Larue Red. Standard for eastern markets; of large size, deep red, an excellent keeper. Pkt. 5c, oz. 15c, 1-4 lb. 56c, lb. \$1.60.

\section{PARSLEY.}

Parsley succeeds best in a rich. mellow soil. It should be sown early in spring, previously soaking the seeds in tepid water.

Donble Curled. A fine dwarf variety, beautifully curled. Pkt. ǰ, oz. $10 \mathrm{c}$.

\section{PARSNIP.}

If by mail, add $8 c$. per $1 \mathrm{~b}$.

Sow as early in the spring as the weather will permit, in drills 15 inches apart, covering half an inch deep, when well up thin out to 5 or 6 inches apart in the row. They are improved by frost.

Long Smooth or Hollow Crown. Standard for general use. Pkt. 5c, oz. 10c, 1-4 lb. $15 \mathrm{c}, 1 \mathrm{~b} .50 \mathrm{c}$.

25 Pkts. Vegetable Seeds for $\$ \mathbf{1 . 0 0}$. 


\section{- PEAS.}

$10 \mathrm{c}$ per packet by mail. Add 15c. per quart if sent by mail.

McLenus Litue Geul. A wrinkled variety, very early, quality good; 1 foot hlgh. pt. 1jc, qt. $25 \mathrm{c}, \mathrm{pk} . \$ 1.5 \mathrm{u}$.

First and Best. Tery desirable, and ripens thoroughly; 2 feet high. pt. 10c, qt. $20 \mathrm{c}, \mathrm{pk} . \$ 100$.

Horsford's Market Garden. A wrinkled variety coming in between Little Gem and Adrancer; 2 feet high pt. $10 \mathrm{c}, \mathrm{qt} .20 \mathrm{c}, \mathrm{pk} . \$ 1.15$

Aaska. 'Tery early smooth blue pea, pt. $10 \mathrm{c}$, qt. 20 pk. $\$ 1.20$.

Champiou of England. One of the most popular sorts known; 5 feet high. Pt. 10c, qt. 20c. pk. $\$ 1.00$

BIack-Eyed Marrowfat. A tavorite in Boston market; large fods ; prolific; 5 feet high, pt. $10 \mathrm{c}$, qt. $15 \mathrm{c}$, pk. $80 \mathrm{c}$.

American Wouder. One of the earliest wrinkled peas in cultivation, fine quality and flavor; ten inches in height. pt. $15 \mathrm{c}$, qt. $30 \mathrm{c}, \mathrm{pk} .81 .75$.

Bliss Abundance Pea. Tery productive; grows from 15 to 18 inches; excellent quality; a second early variety. pt. 15 , qt. $25 \mathrm{c}, \mathrm{pk}$. \$1.25.

Notr's Excelsior. An extra early dwarf wrinkled pea, usually ready for table in 40 or 50 days from planting. It grows about $1 t$ inches high. It is wouderfully productive. pt. $15 \mathrm{c}$, qt. $30, \mathrm{pk} .31 . \overline{\mathrm{j}}$

Prosperity or Gradus. An extra early wrinkled variety. The peas are very early, large and splendid quality; 2 1-2 feet high. pt. $25 \mathrm{c}$, qt. $\pm 0 \mathrm{c}$

Telephone. À tall, wrinkled, marrow, enormously productive and the best quality. Desirable for the $f_{a} m-$ mily garden. Height $t$ feet, pt. $15 \bar{c}$, qt. $25 \mathrm{c}, \mathrm{pk} . \$ 1.50$.

\section{PEPPER.}

Sow in hot bed early in April, and transplant to the open ground when the weather is favorable. They should be planted in warm, mellow soil, in rows 18 inches apart.

\section{Sweet Momutain or Mamumh.}

Rind thick, fleshy and tender; much used for pickling,stuffed like mangoes. Pkt 5̄c, oz. 20c.

Large Bell or Bull Nose. An early kind; the standard variety. large, Pkt. ǰc, oz. 20c.

Chinpse Giant. Grows rery Jarge and uniform; as early as Rubr King and very mild. Pkt. $5 \mathrm{c},{ }^{\prime} \mathrm{oz} .30 \mathrm{c}$.

Long Red Caypune. Ters productive. Pkt. 5c, oz

\section{RADISH .}

If by mail, add $8 \mathrm{c}$ per pound.

Radishes thrive best in light. sandy loam.

OHive Slınped Scarlet. Matures in 25 days; tlerh is crisp and tender. Pkt. 5̄c, oz. 8c, 1-t 1b. 15̄e, lb. 50c.

Loug Scaplet Short Top. The standard sarietr. Pkt. j̃c, oz. Sc, 1-4 lb. 15, 1b. $50 \mathrm{c}$.

Early scarlet Turuip. Round, abrut an inch in diameter, skinscarlet and flesh white. Pkt. 5c, oz. Sc, 1-t lb. $15 \mathrm{c}, 1 \mathrm{~b} .50 \mathrm{c}$.

White 'Tipped Early Scarlet Turuip. Bright scarlet, fading off to pure white at base. and is tender mild in flavor and early. Pkt. ǰc, oz. $8 \mathrm{c}, 1-4$ lb. $15 \mathrm{c}, 1 \mathrm{~b} .50 \mathrm{0}$.

Salsify or Oyster Plant. Improv. ed Mam. Sandwich Island. Pkt.5̃e, oz. $10 \mathrm{c}, 1.4$ 1b. $30 \mathrm{c}, 1 \mathrm{~b} . \$ 1.00$.

25 Pkts. Vegetable Seeds for \$1.00. 


\section{SPINACH.}

If by mail, add $8 \mathrm{c}$ per pound.

Thick Leaf. The standard variety; equally good for spring or fall sowing. $\mathrm{Oz}$. $5 \mathrm{c}, 1-4 \mathrm{lb} .10 \mathrm{c}, \mathrm{lb} .25 \mathrm{c}$.

Long Standing. Except in the characteristic of standing a long time before going to seed, this variety resembles the round leaf. $\mathrm{Oz}$. $5 \mathrm{c}$ 1-4 lb. 10 c, 1b. 25 c.

Victorian. (New) a long standing sort. ()z. 5c, 1-4 lb. 10c, lb. $25 \mathrm{c}$.

\section{SQUASH.}

If by mail, add $8 \mathrm{c}$ per $1 \mathrm{~b}$.

Like all vegetables of this class, it is useless to sow until the weather has become suited for their growth. Manure in ordinary manner by incorporating two or three shovelfuls of well rotted manure with the soil for each hill. For the bush varieties, from three to four feet each way, and for the running sorts from six to eight feet.

Suminer Crookueck. Early productive, good quality. Pkt. 5c, oz. 10c, $1-4$ lb. $20 \mathrm{c}, 1 \mathrm{~b} .60 \mathrm{c}$.

Winter Crookneck. Flesh close grained. Siveet and fine flavored. Pkt. 5c, oz. 10c, 1-4 lb. 20c, Ib. 65 c.

Boston Man'w A much esteemed variety comi $g$ in about ten days later than the Crookneck sorts; a good keeper. Pkt. 5c, oz. 10c, 1.4 lb. $20 \mathrm{c}, 1 \mathrm{~b}$. 50 $\mathrm{c}$.

Essex Fllybial.. It is one of the richest Flavored, finest grained and sweetest squashes, and one of the best keepers. The flesh is thick. rich colored and solid. Pkt. 5c, oz. 10c, $1-4$ lb. $20 \mathrm{c}, 1 \mathrm{~b}, 65 \mathrm{c}$.

Hubbard. Large size, fine grained, dry and of best flavor. Pkt. $5 \mathrm{c}, \mathrm{oz}$. 10c, 1-4 lb. $20 \mathrm{c}, 1 \mathrm{~b} .65 \mathrm{c}$.
Early Yellow Bush Scallop. An early, flat scalloped-shape̊d variety ; color vellow, flesh pale yellow and well-flavored. Pkt. 5c, oz. 10c, 1-4 lb. $20 \mathrm{c}, 1 \mathrm{~b} .60 \mathrm{c}$.

Dellicious. leads all others in quality. Pkt. 10c, oz. 15c.

\section{TOMATO.}

The seeds should be sown in a hot bed about the first of March. About the middle of May the plants may be set in the open ground.

Livingston's Favorite. Ripens early. Pkt. 5c, oz. 20c.

Chalk's Early Jewel. Early, bright scarlet, meat solid. Pkt. 5c, oz $35 \mathrm{c}$.

Matchless. A bright red variety; fruit large and smooth. Pkt. 5c, oz. $35 \mathrm{c}$.

Maule's Imperial. Very smooth, solid; of good size and long keeper Pkt. 5c, oz. 30c.

Earliana. 'The largest extremely early scarlet tomato on the market. Pkt. $5 \mathrm{c}$, oz. $3 \mathrm{uc}$

\section{TURNIP.}

If by Mail add $8 \mathrm{c}$. per $1 \mathrm{~b}$.

Turnips do best in ahighlly enriched, light, sandy or gravely soil.

Eavily Thed Wop Strap Leaf. One of the best for ganeral use. Pkt. 5c, oz. 10c, 1-4 lb. 15c, lb. 40c.

Early Puple 'Lip Milan. The earliest variety in cultivation. The color is bright reddish purple above ground and rlear white underneath. Pkt. 5c, oz. 16c, 1-4 lb. 20c, lb. 60r.

White Eso. A very excellent variety; flesh firm and of fine grain and of snowy whiteness. Pkt. 5c, oz. 10c, 1-4 ib. $15 \mathrm{c}, 1 \mathrm{~b}$. $50 \mathrm{c}$. 
Hutan Bagan or Swedisis. The Ruta Baga or Swedish Turnip is exclusively grown for a farm crop, and is excellent for the table early in the spring. Sow from the 20 th of June to the middle of July.

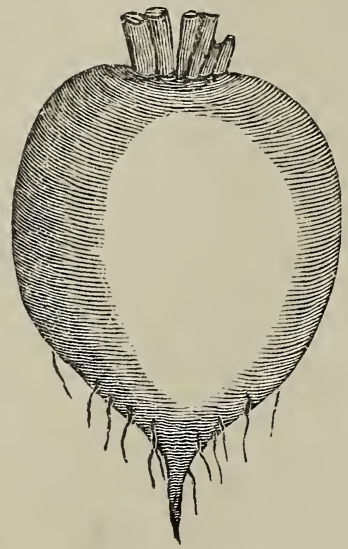

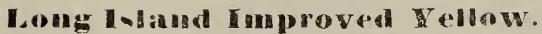
Very large fine yellow flesh. Pkt. 5c, oz, $10 \mathrm{c}, 1.4$ lb. $20 \mathrm{c}, 1 \mathrm{~b} .50 \mathrm{c}$.

Breadstone. A very superior strain of white Ruta Baga. of medium size, smooth, quick growing. flesh fine grained, perfectly white, sweet and tender. Pkt. 5c, oz. 10c, 1-t lb. 20c, lb. $50 \mathrm{c}$

\section{SWEET and POT HERBS}

5 cents per packet.

SAGE. liroad leaved. oz. $15 \bar{c}$.

SUIM MER SA VOKE VEGETABLE PLANTS. CATBACE.

For early setting started in spring.
Eingy Jea'sy Winketield.

Ready April 15. Per 110 60e, per $1,000 \$ 5.00$.

\section{Henderson Eady Sumaner.}

Ready April 15. Per 100 60c, per $1,000 \$ \tilde{0}$ U.

For fall and winter crop, ready July 1.

Auruma King. Per 100 30c, per $1,000 \$ 2.50$.

Premium Flat Dutch.

Per 100 30e, per 1,000\$2.50.

Danish Ball Head.

Per $1103 u^{\prime} c$, per $1,060 \$ 2.50$.

\section{CAULIFLOWER.}

\section{Henderson's Early Snowball}

Ready May 1. Per doz. 20c, per $100 \$ 2.00$.

\section{CELERY.}

Ready June 1ō. Per $1 \hat{0} 075 \mathrm{c}$, per $1,0 \omega 0 \$ 5.00$.

\section{PEPPER.}

Sweet Mountain.

Ready June 1. Per doz. 25̃e, per 100 $\$ 1.25$.

Bull Nose.

Ready June 1. Per doz. 25c, per $100 \$ 1.25$.

TOMATO.

per doz. per 100

Favorite. Pot plants.

Matchless.

Earliana.

Imperial.

Ready May $15 . \quad 35 \mathrm{c} . \quad \$ 2.50$ Box plants at $25 \mathrm{c}$. $\$ 1.25$

25 Pkts. Vegetable Seeds for \$I.00. 


\section{Thurber's Plant List.}

Asteks, ready May 15 th,

Each Dozen

BALSAMS, “" “ “

5 cents \$ $\$ 25$

Begonias Tuberous, single flowers, mixed colors, dry bulb 6 " 60

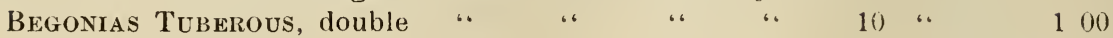

BEGONIAS, in varieties, $\quad 10$ “ 100

Calla Ethiopica, $\quad 20$ “ 200

Canna,

Chrysanthemums, in variety,

Coleus,

150100

1010100

Cuphea, cigar plant,

8 " 75

FEVERHEW,

75

Fuchias, in variety,

Geraniums, double,

Geraniums, single,

GERANIUMS, new varities,

Geraniums, double ivyleived.

Geraniums, scented,

HeLiotrupes,

Ivies, German,

lemon, Verienas,

LOBELIAS,

Manettia, Bicolor,

Pansies, seedlingrs from choice varieties.

Petunias, double.

Petunias, single,

Stocks, mixed eolors.

11) .100

10 " 110

15 “ 150

15 “ 150

$10 \quad \cdots \quad 100$

$10 \quad \cdots \quad 100$

(1) $\cdots 100$

$1.5 \quad 150$

8 6 611

1116100

5) $\cdots$

$15 \quad 150$

11) .. 1 (i)

SALVIA SPLENDENS.

Vinca Variegated Myrtle,

100

Verbenas MaMmoth.

60

Zinnias, ready May $1.5 \mathrm{th}$, 



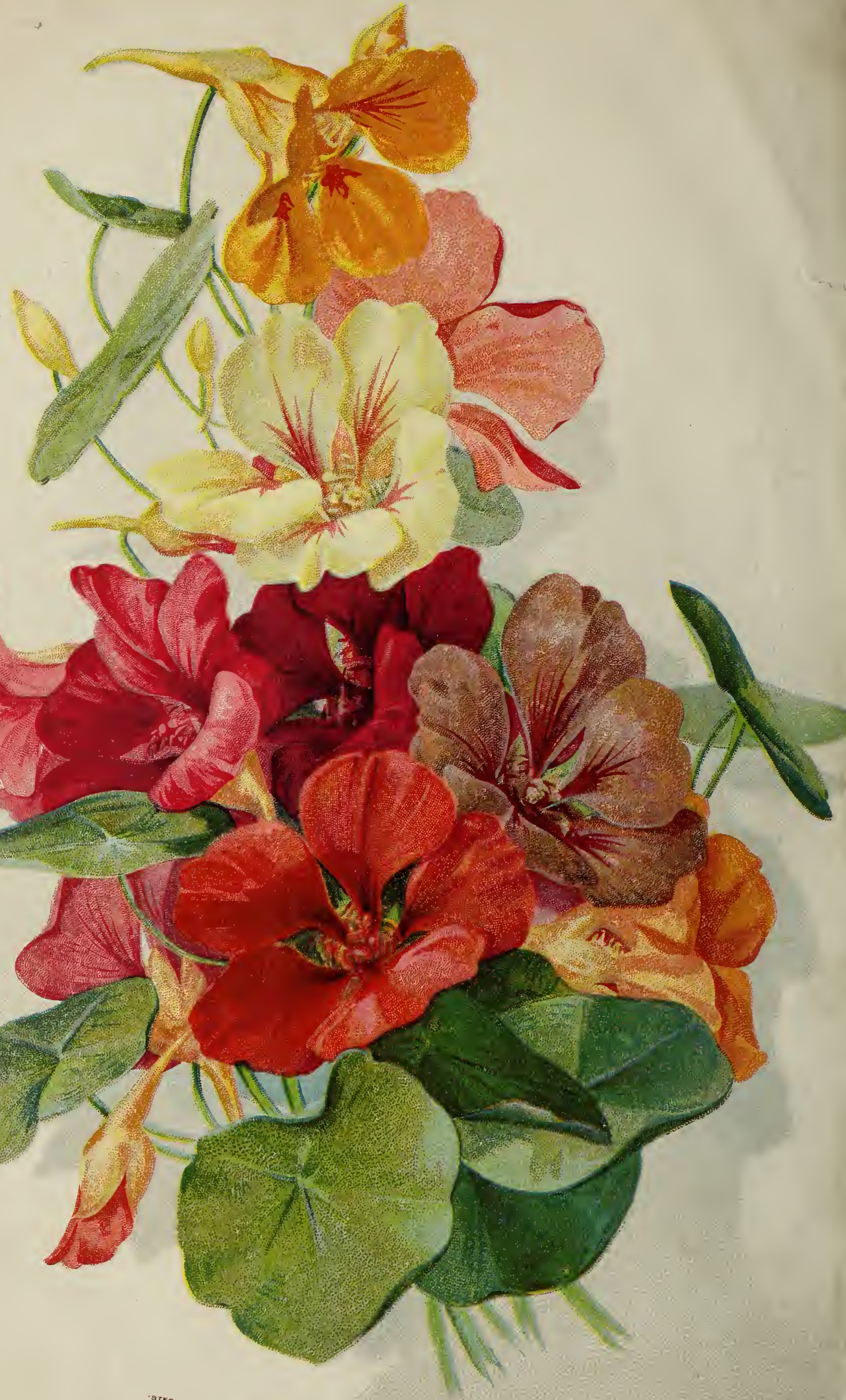

